\title{
PROFESI ADVOKAT: ANTARA HARAPAN DAN KENYATAAN
}

\author{
Oleh: \\ Solehoddin*
}

\begin{abstract}
Lawyer is a honourable profession (officum nobile). And in doing so, he should work under the protection of law, regulation, and ethical codes, and he has freedom on the basis of this respect and personality. As a lawyer namely self-help, sincerity, and openness. He works as a law enforcers having equivalent position with judges, policemen, or attorneys. In fact, in its development, this profession encounters many challenges. For example, the people underestimate this profession since those working on this field show improper behaviors which are irrelevant with the ethical codes. It is not wrong if there is a stigma in this profession that a lawyer is a "junk profession".
\end{abstract}

Kata kunci: Profesi hukum, dan advokat

\section{PENDAHULUAN}

Perkembangan hukum di Indonesia yang semakin hari kurang menjamin kepastian penegakan supremasi hukum dan menjamin adanya rasa keadilan bagi masyarakat menuntut kita untuk selalu berperan aktif dan mengambil posisi sebagai bagian dari unsur penegakan hukum. Perkembangan hukum ini pula menuntut adanya peningkatan kualitas para penegak hukum. Sehinggga nantinya dapat memenuhi tuntutan kebutuhan masyarakat.

Hakim, Jaksa, Polisi dan Advokat merupakan lembaga yang perannya sangat strategis dalam mewakili kepentingan masyarakat. Pada posisi seperti ini peran advokat sangat penting, terutama di dalam Malang menjaga keseimbangan di antara kepentingan negara, pemerintah dan masyarakat.

Oleh karena relasi antara manusia dalam bernegara, berpemerintahan dan bermasyarakat dirasakan semakin komplek, maka peran utama yang tradisional dari advokat untuk hanya mewakili kliennya di depan polisi, jaksa, dan pengadilan saja, tetapi yang lebih penting justru peran di luar kompetensinya yang semakin berkembang dengan semakin kompleknya pola hubungan dan struktur antara manusia dengan lembaga atau badan hukum lainnya. Itulah sebabnya dalam posisi seperti itu pola hubungan antara advokat dengan kliennya tampak semakin eksklusif di dalam suatu sistem bermasyarakat.

Atas dasar itu, advokat tetap memiliki 
peran yang strategis di dalam menjaga hubungan yang semakin komplek tersebut, maka ia harus memiliki kemampuan "profesional", bukan saja dalam lingkup kekuasaan peradilan, tetapi juga dalam lingkup di luar peradilan. Profesionalisme ini tidak hanya dimaksudkan untuk menjaga kepentingan suatu asosiasi profesi semata, tetapi harus berpucuk pada jaminan agar dilindunginya kepentingan masyarakat ${ }^{1}$

Profesi advokat adalah sebuah profesi yang memerlukan keahlian khusus yang rentan terhadap godaan yang akan menjerumuskan advokat bertindak di luar kode etiknya (etika profesinya). Sehingga banyak advokat melakukan $\mathrm{KKN}$ dengan aparat penegak hukum yang lain dan tidak jarang pula advokat tersandung masalah dan menjadikannya mereka berurusan dengan aparat penegak hukum yang lain "tersangka".

Upaya pemberantasan KKN hanya slogan kosong belaka. Bahkan lembaga keadilan sebagai pintu terakhir dari negara Demokrasi pun tidak mampu menumbuhkan rasa kepercayaan masyarakat. Catur wangsa; Hakim, Jaksa, Polisi dan Pengacara seolah luput dari tuntutan pejabat yang bersih dari KKN.Artinya, di jaman Orde Baru atau jaman reformasi pun tak ada bedanya. Yang membedakan barangkali, jika dulu nyogok itu sembunyi-sembunyi, sekarang malahan terangterangan. Baik yang nyogok maupun yang minta disogok, agar urusan perkara atau perkara yang dihadapinya bisa menang. Rasanya langka dan cenderung mustahil di jaman sekarang untuk menemukan penegak hukum yang bebas dari $\mathrm{KKN}^{2}$

' Warkum Sumitro; Mewujudkan Profesionalisme Advokat Di Tengah Krisis Kepercayaan; Makalah Raker Ikadin Malang,3-12-2005)

2 M.Taufiq; Moralitas Penegak Hukum dan Advokat "Profesi Sampah"; Surabaya,Temprina Media Grafika Surabaya.hl. 15.
Melihat kondisi semacam itu maka Advokat harus benar-benar menjalankan profesinya dengan sebenar-benarnya untuk memberikan rasa keadilan dan mencari kebenaran. Jika ada seorang advokat yang melakukan profesinya dengan cara menyimpang, maka mereka selain bisa di jerat dengan hukum pidana, perdata juga advokat yang bersangkutan dapat dilaporkan ke lembaga dimana advokat tersebut bernaung (Ikadin, IPHI, AAI, HAPI.....dII), sehingga mereka dapat diadili di depan dewan kehormatan advokat itu sendiri. Contoh yang paling baru yaitu dilaporkannya advokat senior Todung Mulya Lubis. oleh advokat Paris Hutafea karena mereka dianggap telah melakukan pelangggaran kode etik yaitu disatu sisi dia menjadi kuasa hukum dari salah satu kasusnya BLBI, disisi lain mereka juga menjadi Tim yang menyelesaikan kasus BLBI. Begitu juga sebaliknya jika sepanjang profesi advokat dijalankan sesuai dengan ketentuan UUNo. 18 Tahun 2003 tentang Advokat, dan berpegang tegukh dengan kode etiknya, maka seorang advokat mendapatkan perlindungan dan kekebalan dalam menjalankan tugas keadvokatannya (hak immuniteit).

Kita tidak bisa memungkiri adanya advokat yang berkonspirasi dengan aparat penegak hukum yang lain untuk memenangkan perkara yang ia tangani, mereka tega dan tanpa ada rasa penyesalan dan bersalah, walaupun mereka menjerumuskan orang lain yang tidak bersalah mereka lupa atau pura-pura lupa terhadap adium hukum yang populer sejak kita di bangku kuliah fakultas hukum "lebih baik melepasakan seribu orang yang bersalah dari pada menghukum satu orang tidak bersalah". Kondisi tersebut tidak bisa diberlakukan secara umum (general). Masih banyak advokat yang menjalankann profesinya dengan baik dan bersih. Tidaklah salah jika ada guyonan terhadap para Advokat/lawyer, yaitu bahwa 
advokat memiliki sosok ganda. Sosok yang satu adalah advokat sebagai "learned profesional", sedangkan sosok lainnya sekedar "those who know the judge". Unkapan yang amat dikenal tentang sosok advokat adalah "there are two kinds of lawyers: those who kno the law and those who know the judge."

Bukan hal aneh sekarang dengan istilah 86 (tahu sama tahu) populer di Benteng Terakhir Keadilan alias Pengadilan. Padahal dahulu kita hanya mengenalnya di lingkungan Kepolisian. Celakanya para pengacara muda pun banyak yang terjangkiti penyakit ini. Jika tengah menghadapi perkara atau bersidangan ia bukannya mencari referensi hukum tentang perkara yang ditanganinya. Melainkan mencari referensi siapa hakim atau jaksa yang menangani perkaranya. Sudah dapat ditebak maksudnya agar urusannya lancar dan buntutnya perkara yang ditangani menang. Untuk menghindari atau paling tidak mengeliminir sebagaimana tersebut diatas, maka seorang advokat di dalam menjalankan profesinya harus berpegang teguh kepada kode etiknya.

Ketika kita berbicara tentang etika profesi, yang kita maksudkan adalah normanorma, syarat-syarat, dan ketentuan-ketentuan yang harus di penuhi oleh kelompok orang yang disebut kalangan profesional. Lalu siapakah yang disebut kaum propesional itu? Karena konsep tentang seorang profesional secara intrinsik bersifat normatif, maka siapa yang memenuhi syarat sebagai profesional berbedabeda menurut norma-norma yang harus ditaati. Dengan kata lain, "profesional" merupakan istilah yang dialektis. Para peneliti yang ingin membahas perilaku kaum profesional harus menyelidiki siapakah yang dimaksud profesional $^{3}$.

${ }^{3}$ Kanter,E.Y; Etika Profesi Hukumm; Jakarta Storia Grafika, 2001;61.
Kartono Muhammad dalam makalahnya "profesionalisme dan Kode etik Profesi" Mengutip seorang pakar bernama Myer menyimpulkan bahwa selain memerlukan pendidikan khusus, profesi juga mempunyai manfaat positif bagi masyarakat, disamping mempunyai sikap yang didasari oleh sifat $a l$ truistic, yaitu mengutamakan kepentingan orang lain (masyarakat) di atas kepentingan pribadinya dan, ini yang tidak kalah pentingnya adalah kemandirian atau independensi advokat.

Dalam hubungan itu, Myers sendiri mengutip pendapat Marshall yang menyimpulkan bahwa "The Profesional man, it has been said, does not work ini order to be paid; he is paid in orde that the may work. Every decision he takes in the couse of his career is based on his sense of what is right, not on his estimate of what is profitable". Dengan demikian subyek profesi hukum bisa disebut profesional secara paripurna tidak hanya karena kemampuan untuk menghadirkan perasaan (empati) bahwa profesi hukum sebenarnya merupakan pekerjaan yang syarat dengan aspek pengabdiaan dan pelayanan kepada masyarakat luas, yang mestinya dilakukan dan disertai nilai-nilai luhur dan mulia, seperti: komitment untuk menegakkan keadilan secara konsisten, sikap non kompromis terhadap praktek-praktek judicial corruption, kemauan untuk melindungai dan mengayomi para justisiabel yang hak-haknya secara sewenang-wenang dirampas oleh sesama oknum profesi hukum yang tak bermoral. Seorang profesional hukum, khususnya advokat, harus memiliki 3 (tiga) persyaratan dasar, yaitu pertama, adanya standar minimal intelektuliatas bagi seseorang untuk bisa disebut sebagai profesional di dalam profesi advokat; kedua, dimilikinya suatu standar etika profesi sebagai dasar moralitas 
bagi profesionalisme itu ${ }^{4}$, ketiga, Advokat harus menyadari bahwa mereka adalah aparat penegak hukum, yang setiap saat harus menegakkan hukum (law enforcement) dalam rangka menjamin kemanfaatan (doelmatiqheid) dari aturan itu, tanpa penegakan hukum yang tegas maka aturan normatif tersebut tidak akan berarti.

\section{Advokat sebagai sebuah profesi}

Setiap menusia yang dilahirkan ke dunia mempunyai dua hal yang berbeda yaitu jasmani dan rohani, didalam tubuh yang sehat terletak jiwa yang sehat, begitu juga sebaliknya di dalam jiwa yang sakit terletak tubuh yang tidak sehat. Artinya bahwa manusia didalam menjalani kehidupannya harus selalu menjaga keseimbangan lahir dan bathin. Setiap manusia yang sehat secara rohani pasti memiliki sikap moral dalam menghadapi keadaan-keadaan yang menyertai perjalanan hidupnya. Sikap moral ini timbul didalam hati nurani dari diri manusia itu sendiri.

Dengan demikian, setiap manusia siapun dan apapun profesinya membutuhkan perenungan-perenungan atas moralitas yang terkait dengan profesinya. Dalam kontek inilah lalu timbul suatu cabang etika yang disebut etika s. Etika profesi harus dijalankan oleh setiap orang yang menjalankan profesinya masing-masing tak terkecuali adalah orang yang menekuni profesi hukum.

Dalam diskursus yang serius, istilah profesi ternyata tidak bisa digunakan begitu saja untuk setiap pekerjaan yang dilakukan seseorang, seorang tukang becak. Tukang kebun, pembantu (unskilled), bahkan seorang pelacur tidak dapat dikatagorikan sebagai seorang yang menyandang 'profesi" dalam arti

\footnotetext{
${ }^{4}$ Warkum. Op.cit

s Sidharta; Moralitas Profesi Hukum, Suatu Tawaran Kerangka Berpikir; Bandung, Refika Aditama $2006 ; 1$
}

sesungguhnya. Profesi yang benar-benar profesi dan yang tertua adalah profesi yang berkaitan dengan Churh, Medicine and the Law, yang oleh Kenneth Hudson dikelompokkan sebagai "the learned profession", sebagai "a learned profession". Lawyer mesti memiliki (1) pengetahuan dan ilmu yang luas dan mendalam serta keterampilan yang memadai, (2) mengutamakan etika, (3) wajib senantiasa memperhatikan dan mewujudkan nilai-nilai moral dalam kegiatan nyata keprofesionalannya. Hal ini berkenaan dengan ideal-ideal yang inheren dalam "term" profesi ${ }^{6}$.

Profesi hukum dapat didefinisikan profesi yang memiliki kekuasaan yang yang dibenarkan untuk bersikap dan berprilaku tertentu menurut hukum. Kekuasaan menurut hukum (kewenangan) inilah yang membuat profesi hukum mutlak membutuhkan muatan moralitas yang lebih tinggi dibandingakan dengan profesi-profesi pada umumnya ${ }^{7}$.

Profesi ini lahir karena kebutuhan masyarakat. Mereka terdiri dari orang orang yang memahami hukum, tetapi pendidikan untukmenjadi praktisi hukum sendiri, yakni untuk profesi hakim dan advokat, ternyata awalnya tidak dilakukan di sekolah-sekolah hukum. Pendidikan di Universitas lebih ditujukan pada pendidikan calon dosen. Pada abad pertengahan, mereka yang ingin menjadi hakim dan advokat harus menjalani masa magang terlebih dahulu, kemudian, menempuh ujian khusus.

Advokat adalah sebuah profesi terhormat (officum nobile) yang dalam menjalankan profesinya berada di bawah perlindungan hukum,undang-undang dan kode

\footnotetext{
${ }^{6}$ Marius Bo, E: Sepak Terjang Advokat Dalam Pemberantasan Korupsi Antara Cultured Man dan Watch Dog; Makalah Pelantikan DPC IKADIN Malang tgl 18 Maret 2005;2

' Sidaharta op. Cit.
}

52|Profesi Advokat. . 
etik, memiliki kebebasan yang didasarkan kepada kehormatan dan kepribadian Advokat yang berpegang teguh kepada kemandirian, kejujuran, kerahasiaan dan keterbukaan. Profesi advokat adalah selaku penegak hukum yang sejajar dengan dengan penegak hukum lain seperti jaksa, polisi, maupun hakim, oleh karena itu satu sama lainnya harus saling menghargai antara teman sejawat dan juga antara penegak hukum lainnya. Di dalam pasal 5 UU No. 18 tahun 2003 tentang Advokat menyebutkan bahwa advokat adalah juga berstatus sebagai penegak hukum, bebas dan mandiri yang dijamin oleh hukum dan perundang-undangan.

Kita bisa belajar dari cara pandang seorang advokat senior Soemarno P. Wiryanto yang meminjam konsep Roscoe Pound, mendiskripsikan "Idiologi Profesi", sebagai berikut:

1. Harus ada ilmu (hukum) di dalamnya;

2. Harus ada kebebasan. Tidak boleh ada hubungan dinas;

3. Harus mengabdi kepada kepentingan umum. Mencari kekayaan tidak boleh menjadi tujuan;

4. Harus ada "clienten-Verhouding", yaitu hubungan kepercayaan dan advokat dengan klien

5. Harus ada kewajiban merahasiakan informasi yang diterima dari klien. Akibatnya, advokat harus dilindungi haknya merahasiakan informasi yang diterimanya dari klien.

6. Harus ada immuniteit (hak tidak boleh dituntut) terhadap penuntutan - penuntutan kriminal tentang sikap dan perbuatan yang dilakukan di dalam pembelaan, :

7. Harus ada Code Ethicha (sic) dan Peradilan Code Ethica (sic) oleh suatu Dewan Peradilan Kode Etik;

8. Boleh menerima honorarium yang tidak perlu seimbang dengan hasil pekerjaan atau banyaknya usaha atau jerih payah, pikiran yang dicurahkan di dalam pekerjaan itu, orang tidak mampu harus di tolong cuma - cuma $^{8}$

Dengan demikian maka Advokat sebagai salah satu pilar penegakan hukum, dalam menjalankan profesinya harus tunduk pada norma-norma dalam penegakan hukum itu sendiri, bukan malah sebaliknya profesi advokat dijadikan "profesi sampah". Dimana disana tumbuh kembanganya KKN, Jika hal itu terjadi maka sampai kapanpun penegakan hukum tidak akan pernah tercapai.

\section{Kode Etik Advokat Diperlukan Untuk Menjaga Citra}

Dalam drama Code's Rebellion, Shakes mengatakan, "Let's kill all the lawyers", Bunuhlah semua pengacara (profesional hukum) kalau ingin mengubah negara demokratis menjadi negara otoriter (absolut), atau jika kita ingin negara ini penuh korupsi, bobrok, rusak, dan hancur karena main kuasa dan main hakim sendiri. Pernyataan ini menunjukkan hakikat para penegak hukum (hakim, jaksa, pengacara, notaris, dan polisi) adalah pembela kebenaran dan keadilann. Para pemangku profesi hukum bertugas memberi kepastian hukum kepada pencari kebenaran dan keadilan. Mereka memberikan bantuan hukum secara profesional kepoada klien berdasarkan hukum, keadilan, dan kebenaran. Mereka menjalankan profesinya dengan iktikad baik dan ikhlas. Karenanya, profesi hukum merupakan profesi terhormat dan luhur (officium nobile).

Setiap advokat harus menjaga citra dan martabat kehormatan profesi, serta setia dan menjunjung tinggi kode etik dan sumpah profesi, yang pelaksanaannya diawasi oleh

\footnotetext{
${ }^{8}$ Marius Bo, E. op.cit.

${ }^{\circ}$ E.y. Kanter; op.cit.
}

Profesi Advokat. 
Dewan Kehormatan sebagai suatu lembaga yang eksistensinya telah dan harus diakui setiap Advokat tanpa melihat dari organisasi profesi yang mana ia berasal dan menjadi anggota, yang pada saat mengucapkan sumpah profesinya tersirat pengakuan dan kepatuhannya terhadap kode etik advokat yang berlaku.

Oleh karena profesi advokat merupakan profesi terhormat dan luhur, sudah semestinya profesi ini sekarang sedang digandrungi oleh semua orang terutama para lulusan sarjana hukum sebagai salah satu pilihan utama dan sekaligus panggilan hidupnya untuk melayani masyarakat yang awam tentang hukum. Para mahasiswa yang baru lulus menjadi sarjana hukum berlomba-lomba untuk mengikuti Pendidikan Kekhususan Profesi Advokat (PKPA) yang dibuka diberbagai perguruan tinggi penyelenggara.

PKPA ini adalah merupakan pendidikan yang harus diikuti oleh seorang sarjana hukum untuk memenuhi salah satu syarat formal untuk mengikuti test menjadi advokat. Meskipun syarat-syarat menjadi advokat bertambah berat dibandingkan sebelum keluarnya UU. No. 18 tahun 2003 tentang advokat, tetapi tidak menyurutkan para sarjana hukum untuk menggeluti profesi tersebut. Sebagai profesi yang terhormat dan luhur mendorong para advokat untuk bekerja dengan penuh tanggung jawab dengan mengutamakan kualitas hasil pekerjaannya dengan mengupayakan kebenaran dan keadilan bagi pencari keadilan dan kepastian hukum. Selain Advokat dalam melakukan pekerjaannya mendapatkan profit (honor) tetapi tidak kalah pentingnya yaitu mereka bekerja mendahulukan kepantingan kliennya daripada kepentingan pribadi. Sikap seperti ini akan menghalangi dirinya menjadi calo atau makelar kasus "markus" hukum yang membisniskan profesinya.
Advokat sebagai profesi terhormat dan luhur (officium nobile) tentunya di dalam menjalankan profesi harus menjunjung tinggi kode etiknya, dan mengabdikan dirinya untuk menjunjung supremasi hukum diatas segalanya. Advokat harus menjadi profesi yang dihormati dan dipercaya oleh masyarakat bukan hanya semata-mata karena bobot dan kualitas penguasaan hukum yang dimilikinya atau kehandalan kemampuan intelektual dan ilmu hukumnya yang sangat mumpuni tetapi lebih dari itu seorang advokat harus memiliki integritas diri sebagai pengawal konstitusi.

Di dalam lubuk hati yang paling dalam setiap advokat harus terpatri kata kebenaran dan keadilan sebagai komitmen moral profesinya. Ia harus memiliki kejujuran dan keterbukaan serta menjaga kerahasiaan profesinya. Manakala ia merasa kliennya tidak lagi berkata jujur tetapi membiarkan duit berbicara, ia segera memutuskan hubungannya dengan klien tersebut. Dalam hal ini, ia mesti membina relasi atas dasar saling menghargai dan saling percaya. Dalam menjalankan profesinya ia mempertimbangkan kewajibannya kepada hati nuraninya sendiri, kepada klien, kepada sumpah dan rekan seprofesi, kepada lawan berperkara, kepada pengadilan, dan kepada negara. Dengan begitu, akan terbentuk suatu kesadaran hukum yang berkeadilan pada diri profesional hukum dan para pencari keadilan ${ }^{10}$

Kadangkala advokat di dalam menjalankan profesinya dihadapkan kepada situasi yang sangat dilematis dan krusial, disatu sisi mereka harus berpegang teguh dengan sumpah jabatan dan kode etik sebagai advokat, disisi lain advokat dalam menjalankan profesinya dituntut untuk bisa memenangkan perkara yang ditanganinya. Jika di dalam

\footnotetext{
${ }^{10}$ Magnis Soseno ; Etika Sosial; Jakarta; Gramedia Pustaka Utama, 1996;72-76
} 
menjalankan profesinya advokat dihadapkan kepada situasi sulit tersebut makan advokat harus bisa berkata jujur sesuai dengan hati nuraninya dengan tidak melanggar sumpah jabatan dan kode etik advokat itu sendiri.

Ada sebagian dari para advokat tidak tahan dengan iming-iming (janji-janji) dari kliennya untuk memenangkan perkara yang ditanganinya tanpa memperdulikan sumpah yang ia ikrarkan dan kode etik yang di pegang, sehingga mereka harus bahkan wajib untuk memenangkan perkaranya. Bila hal ini terjadi maka mereka hanya akan menikmati kemenangan sesaat dengan mengorbankan orang lain dan menginjak-injak integritasnya sendiri selaku advokat. Biasanya advokat tersebut bisa bertahan "langgeng", karena masyarakat yang tidak tahu seluk beluh profesi advokat menilai bahwa advokat tersebut dalam menangani perkara selalu menang. Dalam dunia praktek advokat sebagaimana tersebut diatas biasanya dikenal dengan sebutan "Black Lawyer". Kadang kala muncul statmen dari seorang advokat "Black Lawyer" bahwa bagaimanapun tinggi pengetahuan di bidang hukum tetapi kalah juga dengan kewenangan "uang"

Sebaliknya Advokat yang menjalankan profesinya sesuai dengan koridor hukum yang berlaku dan memegang komitmen sumpah jabatan dan kode etiknya, biasanya advokat tersebut dijauhi oleh teman-teman penegak hukum yang lain, karena mereka mengganggap bahwa advokat tersebut tidak bisa diajak kerjasama, ujung-ujungnya perkara yang advokat tangani sering dikalahkan. Dan masyarakat akan menilai bahwa advokat tersebut selalu kalah, ujung-ujungnya mereka tidak mendapatkan perkara. Advokat yang demikian biasanya disebut advokat "White lawyer".
Jika advokat "White Lawyer" dalam menangani kasusnya dikalahkan di peradilan tingkat pertama, biasanya mereka melakukan upaya hukum yang lebih tinggi untuk mendapatkan sutu keadilan dan kebenaran. Jika disetiap tingkat peradilan kondisinya sama seperti apa yang ada di tingkat sebelumnya maka bisa dipastikan bahwa perkara yang mereka tangani sering kandas dan dikalahkan. Maka janganlah heran jika seorang advokat tersebut mengatakan bahwa perkaranya kalah terus karena kliennya tidak punya uang.

Terjadinya sebutan "black lawyer" dan "White lawyer" oleh masyarakat terhadap diri profesi advokat adalah akibat dari sepak terjang dari advokat itu sendiri dalam menjalankan profesinya yang tidak konsisten memegang teguh sumpah jabatan dan profesinya.

Menurur Munir Fuady (dalam Eduardus Marius Bo) ${ }^{11}$ menyebutkan bahwa ada beberapa ciri-ciri advokat hitam adalah:

1. Cenderung bersifat ofensif, karena mereka takut diserang orang, maka umumnya mereka mengambil inisiatif untuk menyerang lebih dahulu.

2. Jika berbicara sering berapi-api karena diharapkan lawan bicara dapat terpengaruh dengan cara bicara berapi-api tersebut, sebab biasanya isi dari pembicaraannya tidak ada atau tidak benar.

3. Mereka menjamin pada kliennya bahwa mereka dapat memenangkan perkaranya.

4. Mereka sudah dengan tepat menyebut nama hakim yang akan memeriksa perkaranya meskipun penunjukan hakim oleh pengadilan belum dilakukan.

5. Perkara mereka sering ditangani oleh hakim yang itu-itu saja.

6. Mereka akan menelpon hakim, jaksa, atau polisi di depan para kliennya bahwa ada

"Eduardus Marius Bo, op.cit. 
hubungan khusus antara pejabat tersebut dengann mereka.

7. Karena mereka mendapatkan uang dengan jalan tidak benar, mereka suka menghambur-hamburkan uang, misalnya untuk pelesir atau membeli dan memamerkan mobil super mewah.

8. Tanpa malu-malu, mereka sering keluar masuk ruang kerja para hakim, jaksa, polisi dan pejabat lain yang berkaitan dengan perkara yang sedang ditanganinya.

9. Apabila ditelusuri nilai akademiknya, umumnya mereka dahulunya merupakan mahasiswa fakultas hukum dengan nilai lulus pas-pasan.

Ada juga beberapa advokat yang dikatagorikan sebagai "advokat Putih" (White Lawyer) dengan ciri-ciri utama:

1. Berhati nurani bersih dan mengedepankan keadilan.

2. Tidak mau di publikasikan secara berlebihan

3. Jarang menemui aparat penegak hukum lainnya (Polisi, Jaksa, dan Hakim) kecuali ketika mereka mendampingi pemeriksaan di Kepolisian, Penyerahan Tersangka ke kejaksaan dan membela di depan persidangan,

4. Dalam penentukan honornya, mereka menentukan sesuai dengan tingkat kesulitan perkara yang ditangani dan tidak ada biaya lain selain biaya yang benar-benar dikeluarkan untuk kepentingan proses persidangan, seperti biaya pendaftaran, biaya sita jamin, eksekusi dll (perkara perdata).

5. Biasanya dibenci oleh aparat penegak hukum lainnya karena mereka di "cap" sok alim.

6. Kritis dalam menyoroti ketidakadilan yang terjadi ditenga-tengah masyarakat.

7. Berpegang teguh pada pendiriannya untuk membela kepentingan kliennya.
Melihat fenomena yang berkembang di masyarakat tentang stikma terhadap advokat dengan sebutan "Black Lawyer" dan "white Lawyer" menggugah kesadaran kita agar supaya advokat didalam menjalankan profesinya harus bepegang teguh kepada sumpah jabatan dan kode etik profesinya sehingga stikma tersebut bisa dihapuskan. Akan tetapi jika fenomena ini berjalan terus tanpa arah yang jelas, maka dikemudian hari profesi advokat tidak lagi menjadi profesi yang terhormat dan luhur dan dikatakan "profesi sampah" oleh masyarakat. Para advokat harus sadar bahwa profesinya bersentuhan dan berorientrasi pada perjuangan kemanusiaan dalam menegakkan kebenaran dan keadilan. Jargon yang selalu didengungkan oleh para pencari dan penegak keadilan adalah tegakkan keadilan walaupun langit runtuh (Fiat justisia ruat et collum)". Tegakkan keadilan walaupun bumi hancur (fiat justisia veriat mondus)". Ini menandakan bahwa advokat bukan hanya sekedar membela perkara "membela yang bayar" tetapi lebih dari itu seorang advokat harus benar-benar melihat kasus yang ditangani dalam perspektif hukum.

Untuk itu diperlukan para profesional hukum (advokat) yang memiliki sejumlah kualitas diri seperti a) sikap kemanusiaan, agar tidak menanggapi hukum hanya secara formal, tetapi selalu mendahulukan hukum secara material dengan mengutamakan penghormatan pada hak asasi manusia, b) sikap keadilan, untuk menentukan apa yang layak bagi masyarakat agar terjamin rasa keadilannya, c) sikap kepatutan, dalam mempertimbangkan apa yang sungguh-sungguh adil dalam suatu perkara, dan d) sikap jujur agar tidak ikutikutan dalam mafia peradilan ${ }^{12}$

12 Theo Hujjibers:, Soal-Soal Pokok Filsafat Hukum, Jakarta;BPK Gunung Mulia, 1975:52-55 
Namun memang disadari pula bahwa orientasi pada "kepentingan" dan "keuntungan": biasa lebih mengedepan. Oleh karena itu advokat perlu merenungkan kembali "ontologi" profesi advokat dengan mengutamakan pemahaman bahwa profesi advokat adalah sebuah kegiatan etis. Sebagai kegiatan etis, seorang advokat, dalam berpikir, bertindak, dan berprilaku, harus ( 1 ) berpegang teguh pada norma etika dan kode etik profesi, (2) menghindari orientasi pada kepentingan dan pencari keuntungan, (3) wajib memperhatikan nilai nilai moral.

Untuk menunjang advokat dalam menjalankan profesinya, maka advokat harus mempunyai komitmen terhadap profesinya bahwa profesi tersebut adalah sebuah kegiatan etis. Jika komitmen tersebut dijalankan maka advokat harus memenuhi standar kompetensi profesi hukum pada umumnya:

1. Memiliki Knowladge bahwa advokat berkewajiban memiliki pemahaman secara utuh tentang hukum dan institusi hukum. Lebih dari itu, harus dapat mengkorelasikannya dengan problema disertai pemecahan kasus yang runtut.

2. Legal Skill bahwa seorang advokat harus mampu mempergunakan metodologi legal analysis yang tepat dalam memcahkan problematika kasus yang dihadapi dalam upaya memberikan legal opini, negosiasi, mediasi, investigasi, riset serta litigasi. Dalam arti pula, advokat harus memiliki legal tecnical capacity yang cukup.

3. Leadership. Bahwa advokat harus memiliki kemampuan manajerial dalam mengaplikasikan knoewledge dan legal skil secara efektif dan efisien dalam menegakkan hukum.

4. Character bahwa advokat harus memiliki watak melayani pencari keadilan secara loyal dan efektif.

5. Capability bahwa seorang advokat harus memiliki kebugaran fisik, psikis dan mental yang memadai dalam melakukan profesinya.

Dengan standar kompetensi yang dimiliki oleh advokat maka akan memberikan inspirasi kepada advokat untuk menegakkan kebenaran dan keadilan serta menjunjung tinggi moralitas. Dengan moralitas yang tinggi akan menciptakan orientasi perjuangan terarah pada upaya menjunjung tinggi "supremasi of moral", dan tidak sekedar "supremasi of law" (apalagi sekedar supremacy of legal positivisian). Perjuangan yang menempatakan "supremacy of moral".

\section{UPAYA UNTUK MEWUJUDKAN ADVOKAT IDEAL}

Untuk mewujudkan advokat yang ideal setidaknya ada empat hal yang perlu menjadi garapan serius, yaitu: pertama, Universitas yang mencetak sarjana hukum, kedua pemantapan pendidikan advokat, ketiga proses rekrutmen calon advokat, keempat pembinaan melalui organisasi profesi advokat.

\section{Universitas Yang Mencetak Para Sarjana Hukum.}

Advokat adalah sarjana hukum yang lulus dari fakultas hukum universitas artinya bahwa universitas yang menghasilkan Advokat untuk itu maka Universitas harus membekali mahasiswanya dengan pendidikan ahklak (budi pekerti, iman dan takwa) dan pengenalan mengenai etika profesi hukum. Kualitas pengetahuan yang dituntut bukan hanya kemampuan teknis, melainkan juga kemampuan menentukan sikap berdasarkan penegetahuan yang mendalam tentang hukum dan maknanya serta ada kerelaan untuk menanamkan kesadaran hukum dalam masyarakat tanpa menuntut suatu imbalan yang berlebihan. 
Para profesional hukum harus mampu menafsirkan hukum yang berklaku secara tepat dan cermat bagi kehidupan bersama, tanpa mengabaikan etika profesinya. Untuk itu profesional hukum mesti otonom, dalam arti bebas dan mandiri dalam menjalankan profesi, tanpa ada tekanan dari pihak lain untuk merekayasa proses pencapaian keadilan hukum $^{13}$

Universitas sebagai lembaga pendidikan dimana di dalamnya terdapat Tri Dharma Pendidikan yaitu terdiri dari Pengajaran, Penelitian dan Pengabdian kepada masyarakat. Universitas dalam melaksanakan Tri Dharma Perguruan tinggi hendaknya harus selalu memasukkan pesan-pesan moral kepada mahasiswanya terutama di bidang pengajaran. Di bidang pengajaran universitas dalam mencetak sarjana hukum harus memberikan forsi yang cukup banyak terhadap mata kuliah yang secara substansi memberikan pesan-pesan moral dan etis kepada mahasiswanya seperti Pendidikan agama, etika profesi, pendidikan kewarganegaran bahkan kepada mata kuliahmata-kuliah lainnya untuk senantiasa memberikan pesan-pesan moral kebaikan. Dengan pemberian forsi yang cukup banyak terhadap mata kuliah yang banyak mengandung pesan-pesan moral, sehingga diharapkan universitas betul-betul mencetak sarjana hukum yang berpengetahuan luas dan bermoral. Kedepan lulusannya dapat bermanfaat bagi negara dan masyarakat dan lebih bijaksana dalam menyikapi permasalahan-permasalahan yang ada.

Bagaimanapun juga universitas juga harus ikut bertanggung jawab secara moral terhadap para alumninya ketika mereka bekerja. Apakah para alumninya bisa menjaga nama baik almamaternya atau sebaliknya, jika para alumninya tidak bisa menjaga nama baik

${ }^{13}$ E. Sumaryono; op.cit;68-82 almamaternya maka universitas yang bersangkutan akan kena getahnya "nama baiknya jatuh". Akan tetapi jika para alumninya berhasil maka universitas tersebut nama baiknya akan selalu dikenang oleh masyarakat. Untuk itu universitas harus terus saling berkomunikasi dengan para alumninya lewat wadah ikatan alumni atau lewat wadah yang lainnya agar supaya kedua belah pihak; yaitu universitas dan alumninya sama-sama memberikan kontribusi yang saling menguntungkan. Bahkan jika ada alumni yang kurang baik "kesandung masalah", maka universitas harus juga memberi solusi cerdas untuk mengatasinya. Universitas yang baik, adalah universitas yang bisa melahirkan sarjana-sarjana yang siap bekerja dan alumninya berhasil untuk menduduki jabatanjabatan strategis baik di pemerintahan maupun swasta (bermanfaat bagi bangsa dan negara). Jangan sampai ada anggapan bahwa universitas hanya pinter mencetak para sarjana-sarjana tetapi tidak memikirkan bagaimana sarjana tersebut bisa bermanfaat.

Untuk itu dalam mencetak sarjana hukum universitas hendaknya juga selain membekali ilmu pengetahuan dibidang hukum juga harus dibekali dengan mata kuliah yang berhubungan dengan moralitas seperti pendidikan agama, etika profesi,ISBD dll. Sehingga para lulusan sarjana hukumnya kelak mengabdikan dirinya menjadi hamba hukum bukan menjadi hamba uang.

\section{Proses rekruitmen Calon Advokat.}

Ketika permasalahan-permasalahan hukum bertambah rumit, Kolusi, Korupsi, Nipotisme (KKN) menjalar dimana-mana, diberbagai sendi kehidupan, Para ahli dan pemerhati hukum berdebat dalam memberikan analisisnya terhadap akar persoalan yang menyebabkan mengapa profesi hukum khususnya advokat begitu terpuruk kinerja dan 
performance-nya. Ada yang berpendapat, bahwa bobroknya kinerja profesi hukum disebabkan oleh pencetak dari para sarjana hukum (universitas) ada juga yang berpendapat karena sistem hukum yang mendasari, ada juga karena adanya kultur masyarakat yang bermental korup, sementara pendapat lain menganggap bahwa faktor moralitas aparat hukum sebagai pemicu utama dari rusaknya citra profesi hukum itu sendiri.

Dari berbagai analisis yang berkembang, dengan argumentasinya masing-masing yang dibangun dari pendekatan dan cara pandang yang berlainan, tentu menghasilkan kesimpulan yang berrbeda pula. Namun demikian, dari sekian banyak analisis yang berkembang, tampaknya yang relevan adalah bahwa buruknya kinerja dan performence profesi hukum (advokat) disebabkan oleh lemahnya sistem rekruitme dan pembinaan profesi yang dilakukan oleh lembagaprofesi hukum ${ }^{14}$.

Sistem rekruitmen para calon advokat sebagaimana diamanatkan oleh Undangundang No. 18 tahun 2003 tentang Advokat, dalam Pasal 3 menyebutkan bahwa calon advokat harus lulus ujian yang diadakan oleh organisasi advokat dan mengikuti magang sekurang-kurangnya 2 (dua) tahun secara terus menerus pada kantor advokat. Selain persyaratan sebagaimana tersebut juga calon advokat harus mengikuti pendidikan kekhususan profesi advokat (PKPA).

Persyaratan-persyaratan rekruitmen yang telah diamanatkan oleh Undang-Undang No. 18 tahun 2003 tentang advokat sudah cukup baik mengingat bahwa para sarjana hukum yang ingin menjadi advokat harus mengenyam pendidikan PKPA dan magang selama 2 tahun, artinya bahwa untuk menjadi advokat tidak cukup berbekal pendidikan Strata 1 saja. Pendidikan lanjutan tersebut (PKPA)

\footnotetext{
14 Warkum: op.cit;5
}

hendaknya tidak hanya memberikan matakuliah yang berbasis praktek seperti Hukum Acara (Perdata, Pidana,Tata Usaha Negara, Agama) saja, tetapi bagaimana PKPA tersebut memasukkan mata-kuliah yang berbasis morality. Hal ini penting diberikan agar supaya kelak menjadi advokat yang profesional dan berbudi luhur.

PKPA menjadi wadah bagi calon advokat untuk mendapatkan keterampilan praktis dan sekaligus berbudi luhur. Jangan sampai nanti ada anggapan dari masyarakat bahwa profesi advokat adalah "profesi sampah" sebagaimana ditulis oleh kalangan advokat sendiri yaitu saudara M. Taufiq ${ }^{15}$. Buku yang ditulis oleh kalangan praktisi sendiri $\mathrm{M}$. Taufiq hendaknya menjadi cambuk kepada kita semua betapa bobroknya profesi ini, meskipun bobrok banyak aparat penegak hukum yang lain cemburu karena banyak para praktisi hukum yang berhasil dalam hal finansial.

Jika kita cermati, sajian mata ajar pada pendidikan khusus profesi advokat oleh PERADI memang telah mencerminkan kebutuhan di atas. Namun, sebagai lembaga pendidikan yang relatif masih baru perlu dilakukan evaluasi dan penyepurnaan secara terus menerus, baik mengenai pengorganisasiannya, kurikulum dan metode pembelajarannya. Sasaran pendidikan khusus ini adalah pada "ranah" kemampuan intelektual calon advokat. Sedangkan ranah kemampuan profesi calon advokat diberikan pada pendidikan permagangan di Kantor advokat. Dalam permagangan perlu diperhatikan hal-hal yang berkenaan dengan jummlah calon peserta magang akan semakin meningkat, sementara kantor-kantor advokat yang tersedia terbatas dengan jenis dan bobot perkara yang beragam, maka perlu adanya pengaturan yang jelas tentang mekanisme peemagangan, bentuk

15 M. Taufiq: op.cit.149

Profesi Advokat. . . I 
aktivitas dan parameter penilaiannya. Bahkan sertifikasi terhadap kantor-kantor yang dipandang layak dan memenuhi standar kualitaas untuk pemagangan juga perlu dilakukan agar tidak terimbas penyakit formalitas yang selama ini melanda bangsa kita 16.

Jika melihat bunyi pasal 3 ayat (1) butir (f) dan (g) bahwa Untuk dapat diangkat menjadi Advokat harus memenuhi persyaratan sebagai berikut:a) warga negara repulik Indonesia, b) bertemapat tinggal di Indonesia, c) tidak berrstatus sebgai pegawai negeri atau pejabat negara, d) berusia sekurang-kurangnya 25 tahun, e) berijazah sarjana yang berlatang pendidikan tingggi hukum sebagaimana dimaksud dalam pasal 2 ayat (1); f) lulus uujuan yang diadakan oleh organisasi Advokat; g) magang sekurang-kurangnnya 2 (dua) tahun terus menerus pada kantor Advokat; $h$ ) tidak pernah dipidana karena melakukan tindak pidana kejahatan yang diancam pidana penjara 5 (lima) tahun atau lebih; i) berperilaku baik, jujur, bertanggungjawab, adil, dan mempunyai integritas yang tinggi. Hal penting yang terkait dengan bunyi pasal tersebut adalah jenjang pendidikan dan permagangan adalah sesuatu yang tidak bisa dipisahkan dalam rangka menciptakan profesi advokat yang ideal.

Permagangan merupakan bagian dari proses rekruitment yang sangat penting dalam membentuk profesi advokat yang terhormat dan luhur (officium nobile). Permagangan merupakan tempat dimana para calon advokat menimba ilmu dalam kerangka praktek (mengasah keilmuannya). Dalam menentukan tempat pemagangan yang perlu diperhatikan adalah; 1) Kontor advokat yang ditunjuk di jadikan tempat magang. 2) Advokat yang mengelola di kantor tersebut (advokat yang tergabung dalam kantor advokat).

\footnotetext{
${ }^{16}$ Warkum: op.cit. 7
}

60 |Profesi Advokat. .
Kantor advokat yang ditunjuk untuk tempat magang adalah kantor advokat yang betul-betul layak dijadikan tempat pemagangan. Dalam menentukan kontor tersebut yang harus diperhatikan adalah kelayakan dari kontor tersebut, diantaranya kantor tersebut tersendiri tidak bercampur dengan tempat lain "rumah", ada pegawainya dan kelengkapan kantor serta menagemennya baik.

Advokat yang dipilih betul-betul advokat yang mempunyai kemampuan intelektual yang baik, senioritas dan berbudi luhur. Janganlah calon advokat dimagangkan kepada advokat yang dikenal dengan sebutan "Black lawyer". Oleh karena pengaruh permagangan terhadap pembentukan profesi advokat sangat besar, maka dalam menentukan permagangan harus selektif. Dalam proses permagangan para calon advokat akan melihat langsung sepak terjang dari advokat seniornya dalam menangani suatu perkara. Jika advokat yang dijadikan tempat permagangan baik, maka kemungkinan besar para calon advokat tersebut nantinya akan menjadi baik pula, tetapi sebaliknya jika dalam menentukan advokat dalam proses permagangan tersebut salah "Black lawyer" maka para calon advokat tersebut nantinya akan terimbas penyakit dari advokat tersebut "Black lawyer". Dan ujung-ujungnya dalam pembentukan profesi adavokat yang terhormat dan berbudi luhur akan pudar.

\section{Pembinaan dan Pengawasan}

Undang-undang No. 18 tahun 2003, Pasal 28 menyebutkan bahwa organisasi advokat merupakan satu-satunya wadah profesi advokat yang bebas dan mandiri yang dibentuk sesuai dengan ketentuan Undang-undang ini dengan maksud dan tujuan untuk meningkatkan profesi advokat. Amanat Undang-undang advokat ini cukup beralasan, karena profesionalisme juga mensyaratkan, diperlukan 
suatu organisasi profesi yang baik, karena lazimnya, legitimasi suatu profesi dapat diperoleh melalui atau adanya suatu organisasi profesi. Biasanya, negara memberikan kewenanganan self regulating kepada suatu profesi tertentu bila profesi itu telah terorganisir dalam suatu organisasi yang baik.

Secara sosiologis, organisasi profesi seperti advokat itu, dimaknai sebagai suatu kelas sosial tertentu sesuai keragaman pendapat dan pandangan tertentu dari masyarakat. Di dalam konteks negara,implikasi lebih lanjutnya, otoritas atas kewenangan tertentu akan diletakkan di dalam profesi tersebut melalui organisasi profesinya.

Di dalam kontek hukum,organisasi profesi advokat sebagai salah satu bagian dari sub sistem peradilan juga harus mengatur relasi dan pola hubungannya dengan lembaga pengadilan institusi penegak hukum lain, seperti kejaksaan,kepolisisan dan kehakiman. Pengetahuan mengenai hukum materiil dan formal dan etika profesi dalam kaitannya dengan penegak hukum lainnya menjadi sesuatu yang juga penting. Sehingga para aparat penegak hukum seiring dan seirama untuk bersama-sama menciptakan law enforcement yang kita idam-idamkan.

Untuk mengawal sepak terjang advokat dalam menjalankan profesinya diperlukan adanya lembaga pengawasan dalam hal ini adalah adalah organisasi profesi advokat itu sendiri, Hal ini dimaksudkan untuk melindungi kepentingan advokat itu sendiri dan masyarakat berkenaan dengan kewenangan tertentu yang diberikan kepada profesi tersebut. Segala upaya untuk mewujudkan tujuan utama itu akan mengakibatkan adanya pengukuhan kepercayaan masyarakat atas profesi advokat. Organisasi profesi ini akan menciptakan nilai dan norma tertentu yang disepakati bersama para anggota untuk mewujudkan pengawasan yang efektif agar penegakan atas disiplin dan kinerja pelayanan profesional dari profesi dapat terus ditingkatkan sembari mengeliminasi berbagai ekses negatif yang selalu saja dapat muncul di suatu organinsasi profesi.

Organisasi profesi advokat inilah yang harus selalu melakukan pembinanan dan pengawasan terhadap para advokat dalam kerangka mewujudkan profesinalismenya dengan tetap mengacu pada kode etik profesi sebagai hukum tertinggi dalam menjalankan profesinya. Jadi, semakin baik dan profesional, organisasi advokat akan semakin mendekatkan pada perwujudan profesionalisme advokat itu sendiri.

Sedangkan pelaksanaan pengawasan sebagaimana bunyi pasal 13 UU. No. 18 tahun dilakukan oleh Komisi Pengawasan yang dibentuk oleh Organisasi advokat. Komisi Pengawasan betul-betul harus menjalankan tugasnya dengan baik dan menindak para angggotanya yang melakukan kesalahan.

Suatu fakta yang tidak terbantahkan bahwa profesi advokat menjadi sorotan publik yang lebih banyak bernuansa negatif-antipatif daripada positif-apresiatif. Sunggguh sebuah ironi yang sangat meyedihkan dan menyakitkan, mengigat bahwa profesi advokat adalah yang terhormat dan luhur (officium nobile) yan semestinya dihormati dan diagungkan di tengah-tengah masyarakat, tetapi kenyataannya, saat ini ia telah jatuh martabatnya menjadi "profesi sampah" yang sangat menjijikkan di hadapan publik.

Untuk mewujudkan profesionalisme advokat yang ideal dalam mengembalikan citra negatifnya, maka semua proses menjadi advokat mulai dari universitas yang mencetak sarjana hukum, rekruitment, pendidikan, pembinaan dan pengawasan melalui organisasi profesi harus diarahkan kepada kemampuan intelektualitas dan budi pekerti (akhlak) melalui 
pelaksanaan terhadap kode atik advokat itu sendiri. Sehingga keseimbangan kemampuan dan budi pekerti tersebut akan menumbuhkan jiwa beradab dan peka terhadap kebenaran dan keadilan. Apapun yang kita lakukan sekarang semua akan dipertanggungjawabkan kepada Allah, SWT. Mudah-mudahan kita selalu diberi petunjuk, rahmat dan safaat dari Allah. Amiin.

$-000-$

\section{DAFTAR PUSTAKA}

Soseno, F. Magnis ; Etika Sosial; Jakarta; Gramedia Pustaka Utama, 1996.

Sidharta; Moralitas Profesi Hukum, Suatu Tawaran Kerangka Berpikir; Bandung,Refika Aditama 2006

Sumaryono, E; Etika Profesi Hukum: normaNorma Bagi Penegak Hukumm" (Yogyakarta: Kanisius, 1995)

Sumitro, Warkum; Mewujudkan Profesionalisme Advokat Di Tengah Krisis Kepercayaan; Makalah Raker Ikadin Malang,3-122005)

Kanter,E.Y; Etika Profesi Hukumm; Jakarta Storia Grafika, 2001

Taufiq.M; Moralitas Penegak Hukum dan Advokat "Profesi Sampah"; Surabaya,Temprina Media Grafika Surabaya.

Marius Bo, E: Sepak Terjang Advokat Dalam Pemberantasan Korupsi Antara Cultured Man dan Watch Dog; Makalah Pelantikan DPC IKADIN Malang tgl 18 Maret 2005

Theo Hujjibers: Filasafat Hukum; Yogyakarta: Kanisius 1990

Notohamidjoyo, O; Soal-Soal Pokok Filsafat Hukum: Jakarta;BPK Gunung Mulia, 1975

UU. No. 18 Tahun 20003 tentang Advokat

Kode Etik Advokat 